\title{
SEASONAL EFFECTS OF QUARRY ACTIVITIES ON LIVER, KIDNEY AND HEMATOLOGICAL PARAMETERS IN ALBINO RATS HOUSED IN THE PREMISES OF A QUARRY SITE
}

\author{
Francis Ugochukwu Madu \\ Department of Biochemistry, Abia State University, Uturu Nigeria
}

\begin{abstract}
This study sought to determine the impacts of quarry activities on the liver, kidney and hematological parameters of albino rats housed in the premises of the quarry site. Sixty male albino rats (Rattus novergius) aged 8 weeks and weighed between 115.5 to $128.6 \mathrm{~g}$ were used in this study. They were housed in six wire cages with five 5 rats in each cage. Group 1 served as the control which was housed at a distance of $7.2 \mathrm{~km}$ from the quarry site. Group 2 was housed at the crusher location of the quarry site while groups 3,4,5,6 were housed at the administration block, gate, plant house and drilling pit positions of the quarry site respectively. The results obtained reveal that the activities of serum alanine transaminase (ALT), aspartate transaminase (AST), alkaline phosphatase (ALP) and the concentrations of total protein, albumin and bilirubin differed in samples from different activity areas of the quarry site. Generally, levels of ALT, AST, ALP and bilirubin increased significantly $(p<0.05)$ whereas the levels of total protein and albumin decreased significantly $(p<0.05)$ when compared to the control. All the analyzed kidney function parameters were significantly higher $(\mathbf{p}<0.05)$ in the test samples than in the control samples. They were also significantly higher $(p<0.05)$ in the dry season than in the wet season. Levels of hemoglobin $(\mathrm{Hb})$, packed cell volume (PCV), red blood cell (RBC) and mean cell hemoglobin concentration (MCHC) were significantly lower $(p<0.05)$ in the test samples than in the control sample in both seasons whereas, the levels of white blood cell (WBC), mean cell volume (MCV) and mean corpuscular hemoglobin (MCH) were significantly higher $(\mathbf{p}<0.05)$ in test samples than the control in both seasons. There was a clear and noticeable adverse effect of the quarry on the liver, kidney and
\end{abstract}

hematological parameters of the albino rats. Therefore, workers in the quarry are at risks of anemia, kidney and liver diseases.

Key Words: Albino rats, alkaline phosphatase, alanine transaminase, aspartate transaminase, anemia, quarry.

\section{INTRODUCTION}

Quarry workers are exposed to various hazards resulting from the inhalation of air borne particulates and these pose a lot of danger to their health and safety. Aigbokhaode et al., (2011) reported that there is lack of awareness of these hazards associated with working in the quarry industry and thus poor use of safety equipment. Quarry workers are also exposed to dust containing silica which can lead to silicosis, an irreversible lung disease resulting in inflammation of the lungs and shortness of breath which may continue even after exposure (Ugbogu et al., 2009).

Quarry dust stimulates cellular inflammation in vivo (Ugbogu et al., 2009). Inhalation of dust leads to the formation of discrete silicotic nodules in rats. This can impair alveolar macrophage clearance functions which cause progressive lesions and pneumonites (Ibrahim and Selim, 2018).

Exposure of quarry workers to particulate pollution, coupled with the general non-use of protection gadgets predisposes them to several health problems. This study therefore aimed at assessing the impacts of quarry activities on the kidney, liver, and hematological parameters of quarry workers, using animal models. 


\section{International Journal of Engineering Applied Sciences and Technology, 2020 \\ Vol. 5, Issue 4, ISSN No. 2455-2143, Pages 521-532 \\ Published Online August 2020 in IJEAST (http://www.ijeast.com)}

\section{MATERIALS AND METHODS}

\section{Area of Study}

The quarry site lies within latitude $05^{\circ} 50^{\prime} 18^{\prime \prime} \mathrm{N}$ of the equator and longitude $07^{\circ} 25^{\prime} 17^{\prime \prime} \mathrm{E}$ of the Greenwich Meridian at Uturu Abia State Nigeria.

\section{Animal Sampling}

Sixty (60) male albino rats (Rattus novergius) aged 8 weeks and weighed between 115.5 to $128.6 \mathrm{~g}$ were used in this study. They were housed in six (6) wire cages with five (5) rats in each cage. Group 1 served as the control which was housed at a distance of $7.2 \mathrm{~km}$ from the quarry site. Group 2 was housed at the crusher location of the quarry site while groups 3,4,5,6 were housed at the administration block, gate, plant house and drilling pit positions of the quarry site respectively. All animals were allowed free access to feed and water ad libitum throughout the sampling period. The experimental animals were housed for ninety (90) days in each season (wet and dry seasons) and were sacrificed. The animals were anaesthetized in a desiccator containing cotton wool soaked in chloroform then sacrificed.

\section{Blood Sample Collection}

After the sacrifice of the rats, blood samples were collected by cardiac puncture from each animal into dry test tubes. The blood sample was divided into two. The first part was dispensed in heparinized tubes for hematological analysis. The second part of the blood sample was allowed to stand for about 15 minutes to clot and further spun in a centrifuge at 4000rpm for 10min. Serum was separated from the clot with Pasteur pipette into sterile sample tubes for the measurement of liver and kidney functions.

\section{Method of Analysis}

\section{Liver Function Tests}

\section{Determination of Serum Alkaline Phosphatase (ALP) activity}

Exactly $32 \mu \mathrm{l}$ of serum from the albino rats was applied to the test strip and allowed to flow into the reaction zone. The formation of dye (blue coloration) which is proportional to the activity of ALP was measured kinetically at $405 \mathrm{~nm}$ using an autoanalizer. The result was displayed after 135 seconds.

\footnotetext{
Determination of Serum Aspartate Transaminase (AST)
}

Exactly $32 \mu 1$ of serum from the rats was applied to the test strip and allowed to flow into the reaction zone. The formation of the dye (blue coloration), which is proportional to the activity of AST was measured kinetically at $546 \mathrm{~nm}$ using an autoanalyzer. The result was displayed after 124 seconds.

\section{Determination of serum alanine transaminase (ALT) \\ Exactly $32 \mu 1$ of serum from the rats was applied to the test strip and allowed to flow into the reaction zone. The formation of dye (blue coloration) which is proportional to the activity of ALT was measured kinetically at $546 \mathrm{~nm}$ using an auto-analyzer. The result was displayed after 140 seconds.}

The determination of bilirubin was done using the spectrophotometric method as described by Beckman (2007). The method described by Roberto et al., (2013) was used in the determination of serum albumin.

\section{Kidney Function Test}

The method as described by Burtis et al., (2012) was used in the determination of serum urea. Serum creatinine was determined using the method described by Nisha et al., (2017). The methods described by Teco (2017) were used in the determination of serum potassium and sodium while the method described by Mohammed and Inuwa (2012) was used in the determination of serum chloride. Serum bicarbonate $\left(\mathrm{HCO}_{3}{ }^{-}\right)$was determined by the method described by Chema (2016).

\section{Determination of Hematological parameters}

The method of cynomethemoglobin as described by Khan et al., (2013) was used in the determination of hemoglobin. Packed cell volume (PVC) was determined by the centrifuge method as described by Khan et al., (2013). The method of formol citrate solution counting as described by Khan et al., (2013) was used in the determination of red blood cell (RBC). Turk's solution method as described by Khan et al., (2013) was used the determination of white blood cells (WBC).

Mean Cell Volume (MCV), mean corpuscular hemoglobin $(\mathrm{MCH})$ and Mean Cell Hemoglobin Concentration (MCHC) were determined by calculation method as follows:

$\mathrm{MCV}=\frac{\mathrm{PCV} \times 10}{\mathrm{RBC}}$




$\begin{array}{ll}\mathrm{MCH} & =\frac{\mathrm{Hb} \times 10}{\mathrm{RBC}} \\ \mathrm{MCHC} & =\frac{\mathrm{Hb} \times 100}{\mathrm{PCV}}\end{array}$

\section{Statistical Analysis}

Statistical analyses were carried out with the use of Analysis of variance (ANOVA) and standard Tdistribution test using statistical package for social sciences (SPSS), version 20 and group mean were compared for significance at $\mathrm{p}<0.05$.

\section{RESULT AND DISCUSSION}

The results obtained from the present study reveal that the activity of serum ALT, AST, ALP and the concentrations of total protein, albumin and bilirubin differed in samples from different activity areas of the quarry site. Generally, levels of ALT, AST, ALP and bilirubin increased significantly $(p<0.05)$ whereas the levels of total protein and albumin decreased significantly $(\mathrm{p}<0.05)$ when compared to those of samples from the control. Raised levels of serum transaminases (ALT and AST) in the rats suggest damage to the structural integrity of the liver. This usually causes leakage of ALT and AST from the liver cytosol into the blood stream (Offor et al., 2017). High activities of ALT and AST indicate cellular necrosis, high liver microsomal membrane fluidity and alteration in the liver tissue (Gowda et al., 2009). On the other hand, increased activity of ALP as seen in the results of this study points to biliary damage or an obstruction of the biliary tree which hinders blood flow to the liver (Farida et al., 2012). High concentration of bilirubin in rats used in the present study is likely because of increased destruction and blockage of biliary tract. Lower level of total protein and albumin recorded in this study suggests hepatic damage. This may be caused by decrease in hepatic DNA and RNA induced by heavy metal intoxication or may be due to decreased utilization of free amino acids for protein synthesis (Offor et al., 2017). 


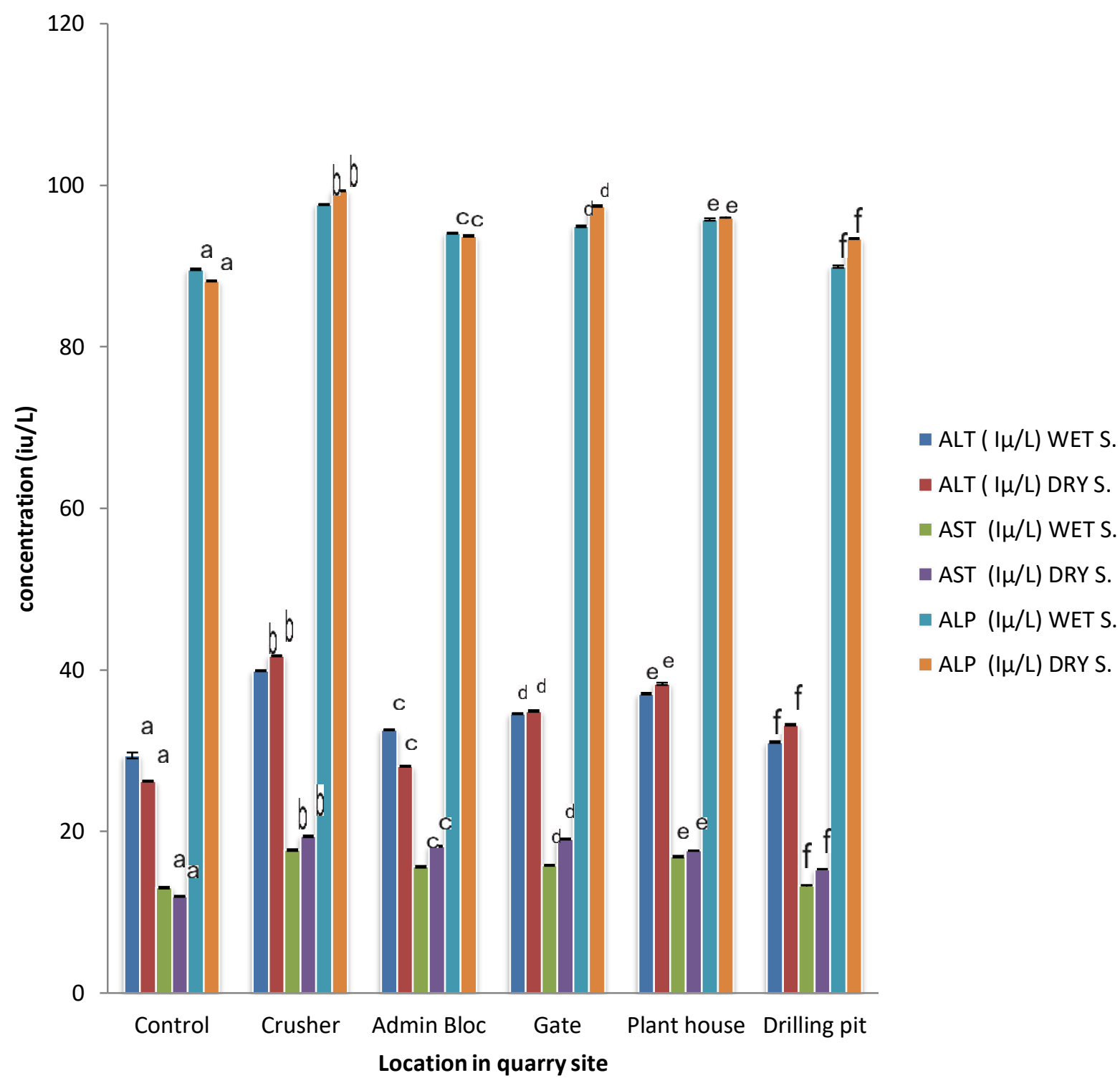

Results represent mean \pm standard deviation of triplicate results obtained $(n=3)$. Bars of the same color having different letters of alphabet are statistically different $(\mathrm{p}<0.05)$ using Least Significant Difference (LSD). Legend: Wet $\mathrm{S} .=$ Wet season, Dry S. = Dry season.

Figure 1: Concentrations of liver function test parameters (ALT, AST and ALP) in the albino rats exposed to quarry dust at various locations in Ugwuele quarry site, Uturu. 


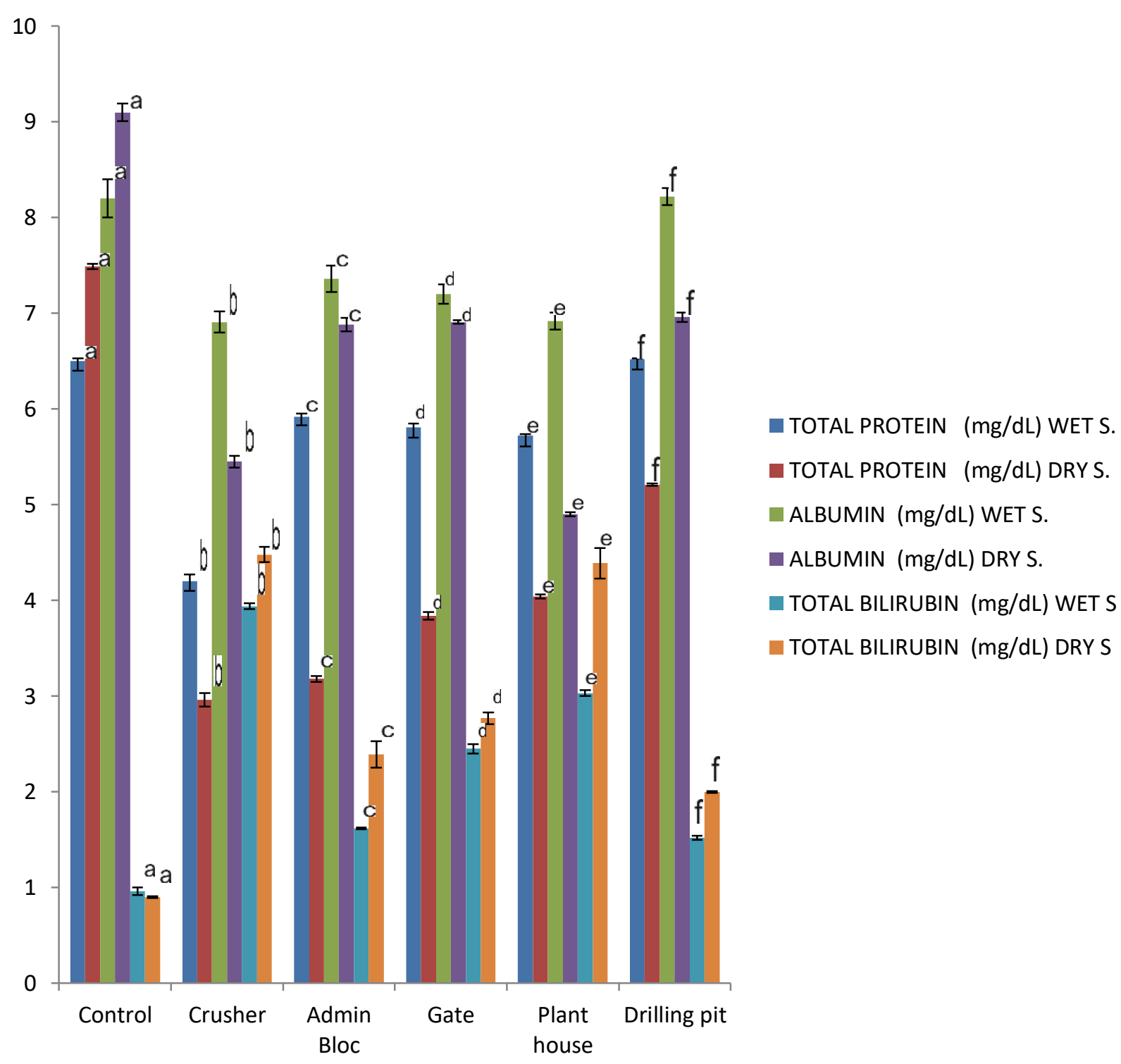

Results represent mean \pm standard deviation of triplicate results obtained $(n=3)$. Bars of the same color having different letters of alphabet are statistically different $(\mathrm{p}<0.05)$ using Least Significant Difference $(\mathrm{LSD})$. Legend: Wet $\mathrm{S} .=$ Wet season, Dry S. = Dry season.

Figure 2: Concentrations of liver function test parameters (Total protein, Albumin and Total bilirubin) in the albino rats exposed to quarry dust at various locations in Ugwuele quarry site, Uturu. 


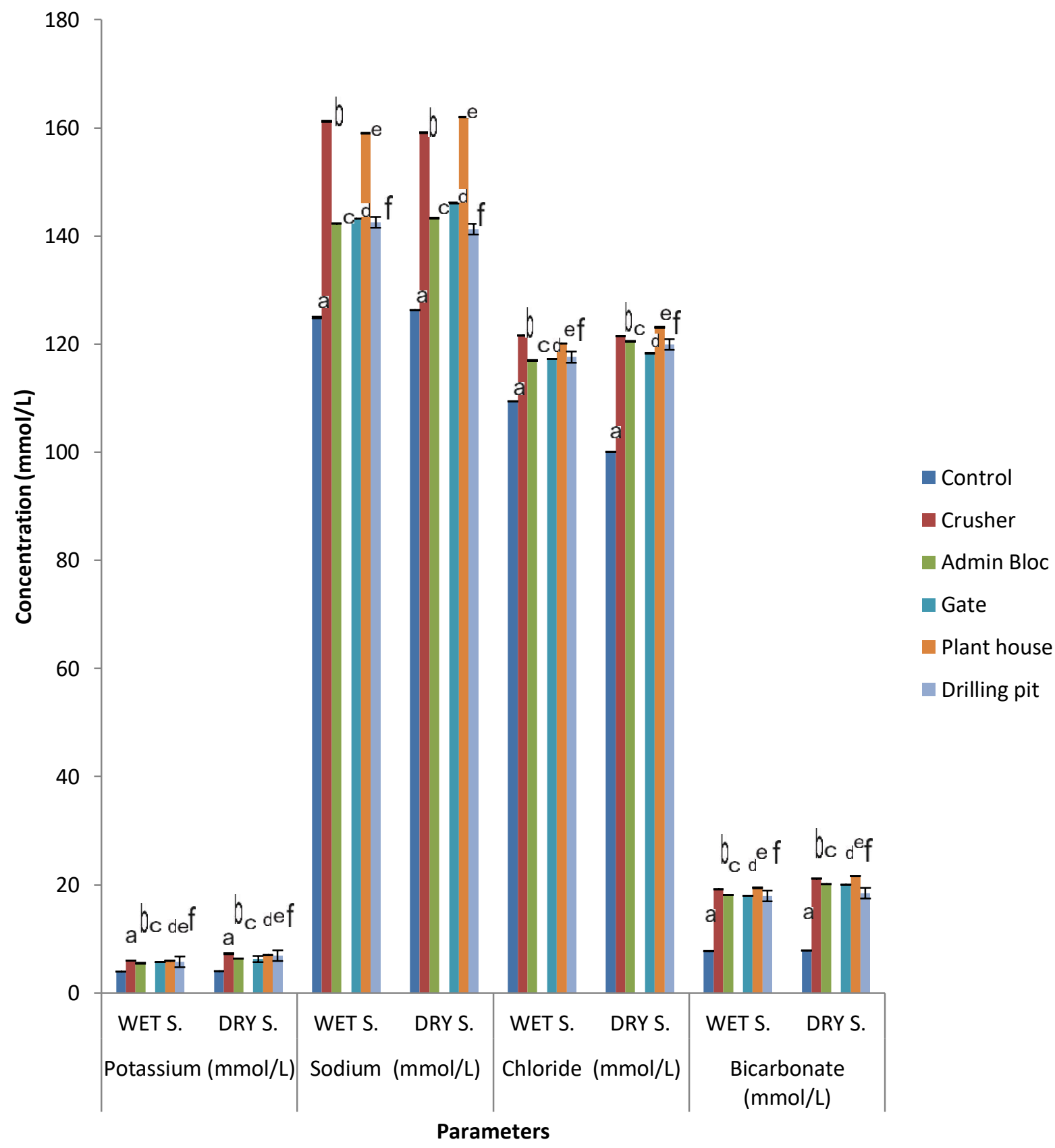

Results represent mean \pm standard deviation of triplicate results obtained $(n=3)$. Bars of the same color and parameter having different letters of alphabet are statistically different $(\mathrm{p}<0.05)$ using Least Significant Difference (LSD). Legend: Wet S. = Wet season, Dry S. = Dry season.

Figure 3: Concentrations of kidney function test parameters $\left(\mathrm{K}, \mathrm{Na}, \mathrm{Cl}^{-}\right.$and $\left.\mathrm{HCO}_{3}{ }^{-}\right)$in the albino rats exposed to quarry dust at various locations in Ugwuele quarry site, Uturu. 


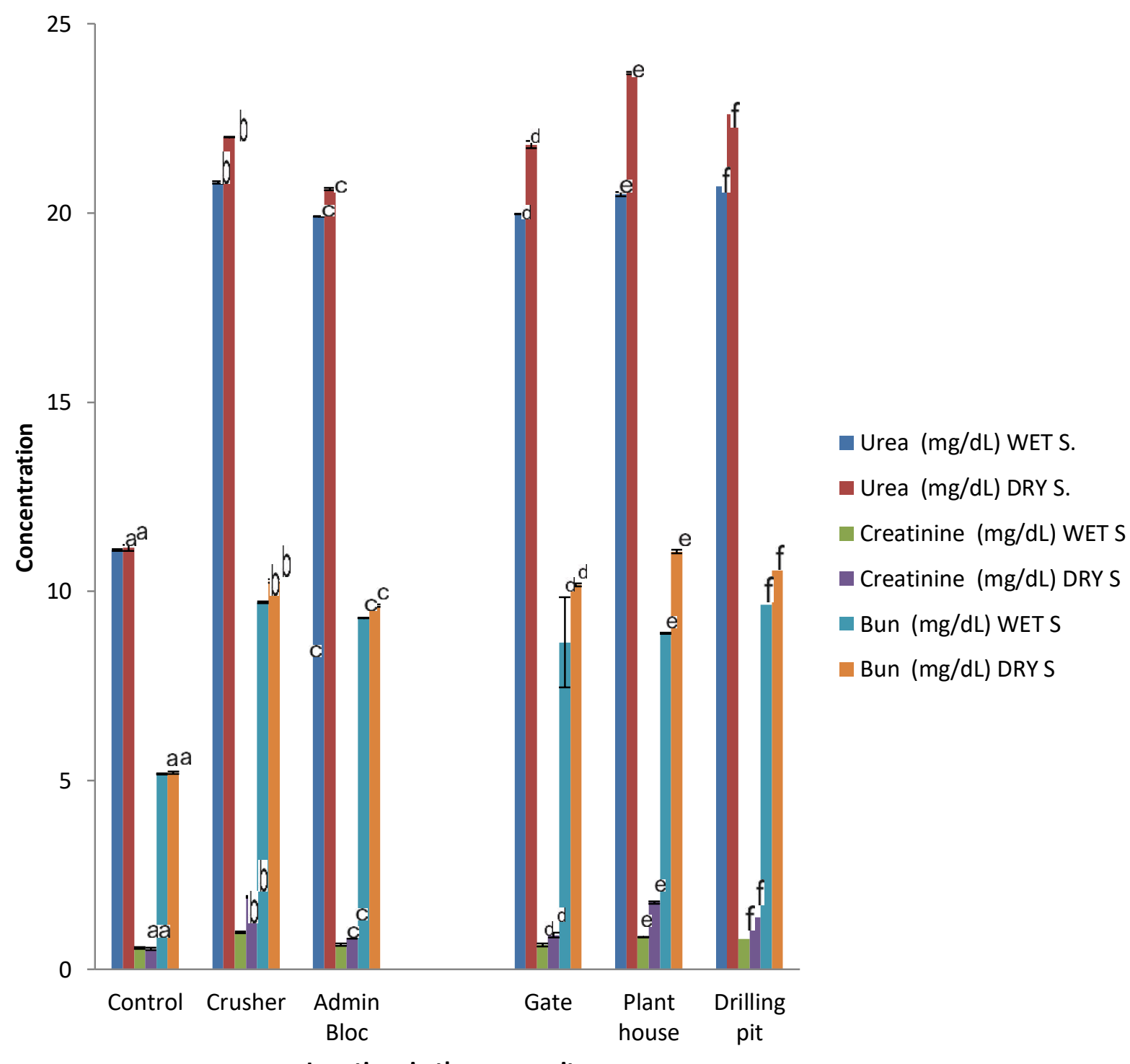

Results represent mean \pm standard deviation of triplicate results obtained $(n=3)$. Bars of the same color having different letters of alphabet are statistically different $(\mathrm{p}<0.05)$ using Least Significant Difference (LSD). Legend: Wet $\mathrm{S} .=$ Wet season, Dry S. = Dry season.

Figure 4: Concentrations of kidney function test parameters (Urea, creatinine and BUN) in the albino rats exposed to quarry dust at various locations in Ugwuele quarry site, Uturu.

Overall, all these liver dysfunctions and diseases diagnosed in rats used in the present study area may be due to the negative impacts of toxicants present in the quarry dust. The results obtained in the present study also reveal that serum ALT, AST, ALP and total bilirubin levels were significantly higher $(\mathrm{p}<0.05)$ in the dry season than in the wet season.
Total protein and albumin levels were significantly lower $(\mathrm{p}<0.05)$ in the dry season than in the wet season. This may be attributed to higher level of dust generated during the dry season.

The results obtained from the present study indicate that all the analyzed kidney function parameters were significantly higher $(\mathrm{p}<0.05)$ in the test samples than 


\section{International Journal of Engineering Applied Sciences and Technology, 2020}

Vol. 5, Issue 4, ISSN No. 2455-2143, Pages 521-532

Published Online August 2020 in IJEAST (http://www.ijeast.com)

in the control samples. They were also significantly higher $(\mathrm{p}<0.05)$ in the dry season than in the wet season. This shows that the quarry impacted negatively on the kidney of the rats. Edmund and David, (2006) and Gowda et al. (2010) reported similar results in albino rats. Electrolyte panel is often used to check electrolyte or acid base imbalance in an organ. In the kidney function test, potassium is the most convincing electrolyte marker of renal failure (Gowda et al., 2010). The increased serum potassium, obtained in this study is caused by decreased filtration and secretion of potassium in distal tubule during renal failure. Sodium is the major cation of the extracellular fluid and helps in the regulation of osmotic pressure and water balance between intracellular and extracellular fluids. An increase in sodium concentration as observed in this study may indicate impaired sodium excretion or dehydration. Chloride is the major anion of extracellular fluid and it is useful in maintaining acidbase balance. Increased chloride concentration recorded in this study may indicate hyperchloremic metabolic acidosis. Bicarbonate content represents the concentration of carbon (iv) oxide dissolved in the serum. Increased bicarbonate concentration as recorded in this study may be an indication of pulmonary disease, poor renal function amongst other diseases. Urea is produced during the catabolism of protein and amino acids. It is a nitrogenous compound. Urea is filtered out of blood by the glomerulli of the kidney and partially reabsorbed with water. Increased urea levels may indicate renal disease. Cretinine is a product of the catabolism of muscle cretinine phosphate. It is excreted by glomerular filteration and tubular secretion. Increased levels of cretinine as recorded in this study may indicate renal failure (Edmund and David, 2006). Also, the increased level of blood urea nitrogen (BUN) recorded in the study may indicate blockage of the urinary tract by a kidney stone, kidney disease or failure (Gowda et al., 2010). 


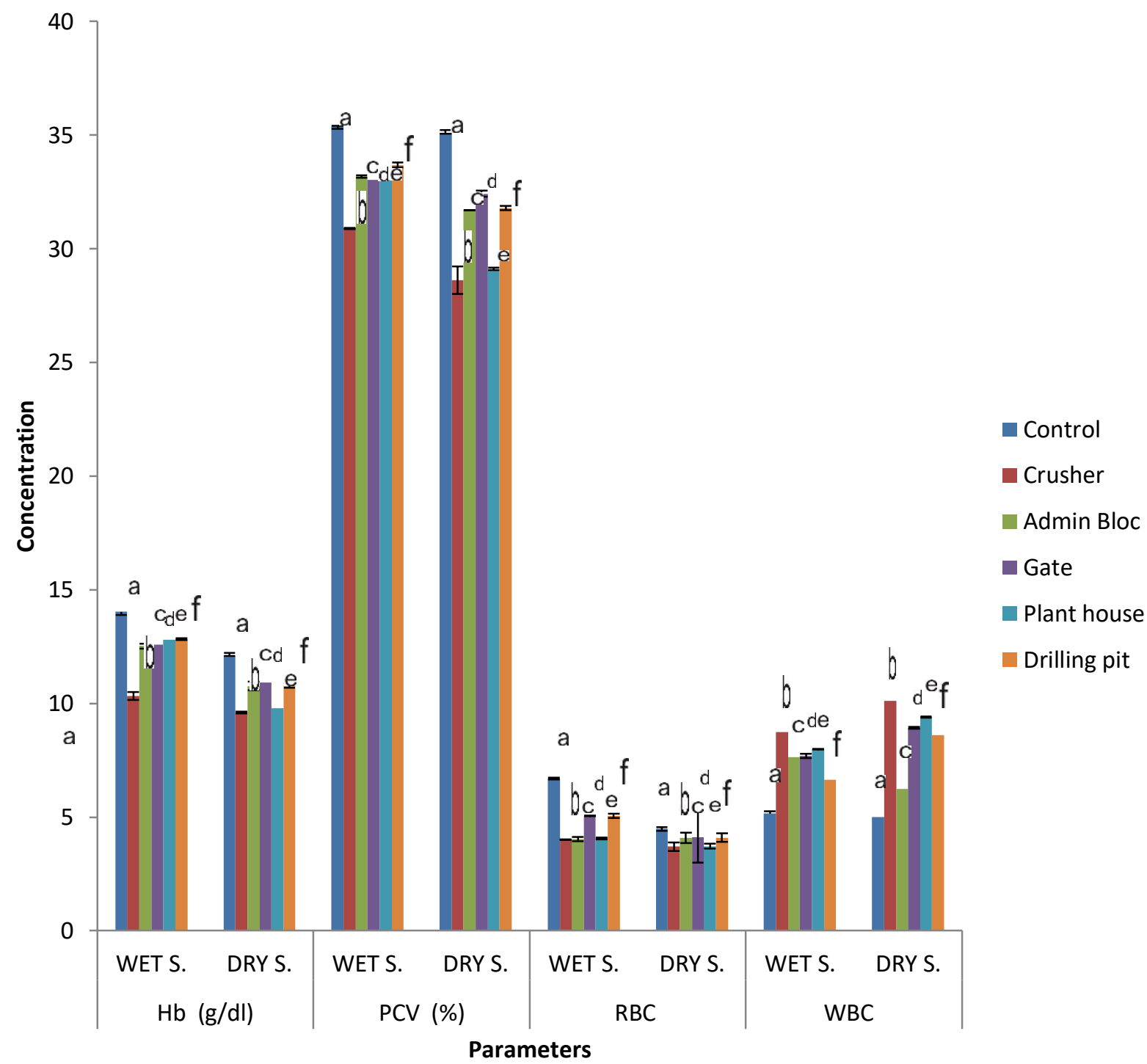

Results represent mean \pm standard deviation of triplicate results obtained $(\mathrm{n}=3)$. Bars of the same color and same parameter having different letters of alphabet are statistically different $(\mathrm{p}<0.05)$ using Least Significant Difference (LSD). Legend: Wet S. = Wet season, Dry S. = Dry season.

Figure 5: Concentrations of hematological test parameters ( $\mathrm{Hb}, \mathrm{PCV}, \mathrm{RBC}$ and $\mathrm{WBC})$ in the albino rats exposed to quarry dust at various locations in Ugwuele quarry site, Uturu. 


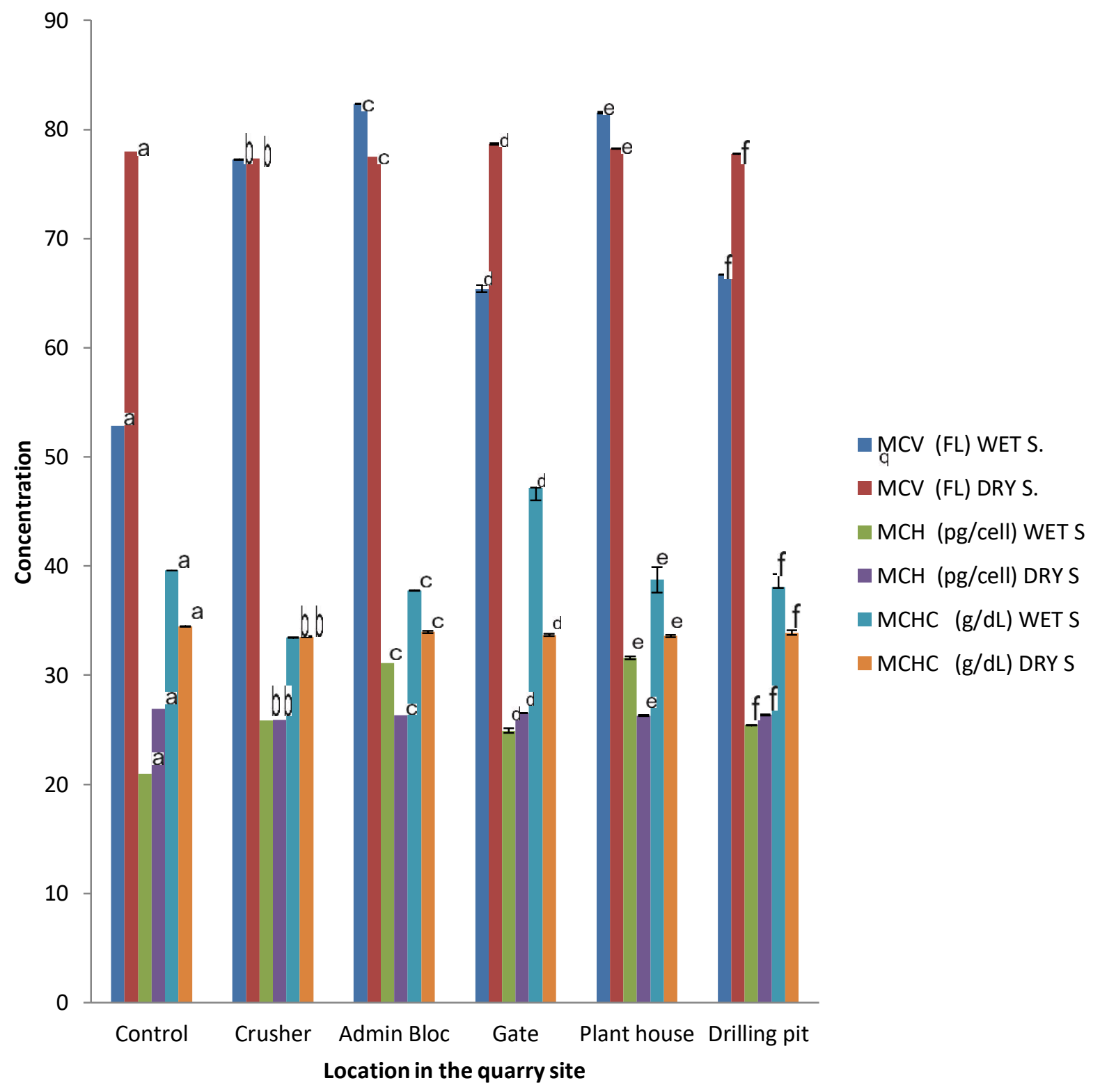

Results represent mean \pm standard deviation of triplicate results obtained $(n=3)$. Bars of the same color having different letters of alphabet are statistically different $(\mathrm{p}<0.05)$ using Least Significant Difference (LSD). Legend: Wet S. = Wet season, Dry S. $=$ Dry season.

Figure 6: Concentrations of hematological test parameters (MCV, MCH and MCHC) in the albino rats exposed to quarry dust at various locations in Ugwuele quarry site, Uturu.

The results from this study reveal that the concentrations of the hematological test parameters differed in test samples from different areas of activity of the quarry. The results also show that the levels of $\mathrm{Hb}, \mathrm{PCV}, \mathrm{RBC}$ and MCHC were significantly lower $(\mathrm{p}<0.05)$ in the test samples than in the control sample in both seasons whereas, the levels of $\mathrm{WBC}, \mathrm{MCV}$ and $\mathrm{MCH}$ were higher than the control in both seasons. This indicates that the quarry 


\section{International Journal of Engineering Applied Sciences and Technology, 2020 Vol. 5, Issue 4, ISSN No. 2455-2143, Pages 521-532 \\ Published Online August 2020 in IJEAST (http://www.ijeast.com)}

impacted negatively on the hematological parameters of the rats. Hemoglobin measures the amount of the oxygen-carrying protein (hemoglobin) in a volume of blood. It gives an indication of the ability of the blood to oxygenate the tissue. Low levels of hemoglobin $(\mathrm{Hb})$ as recorded in this study indicates anemia. This low level of hemoglobin may be due to the effect of high levels of toxic substances in the quarry dust. Packed cell volume (PCV) measures the percentage of red blood cells in the total volume of blood. The results from this study show decreased PCV in the test samples and this indicates anemia (Ogugbuaja et al., 2004). The red blood cell (RBC) count is the number of red blood cells per cubic millimeter of blood. A decrease in the RBC of the test samples reported in this study may have resulted from decrease in the number of red blood cells or decrease in hemoglobin content. This agrees with the work of Ogugbuaja et al., (2004) who reported that dust particles may cause damage to the bone marrow leading to peripheral cytopenia. This in turn causes decreased RBC. White blood cells (WBCs) play a key role in the immune system. They surround and destroy foreign organisms by phagacytosis. They also produce and transport antibodies in response to antigens. The increased WBC reported in the test samples may be attributed to the simulation of the immune system by the dust particles and their contents. Red blood cell indices (MCV, $\mathrm{MCH}$, and $\mathrm{MCHC}$ ) are used to diagnose the type of anemia when hemoglobin levels are low. High levels of MCV reported in the test samples may indicate pernicious anemia and hepatic disease (Wanda, 2018). $\mathrm{MCH}$ measures the amount, or the mass of hemoglobin present on average in one RBC. The results from this study show that $\mathrm{MCH}$ increased significantly $(\mathrm{p}<0.05)$ in the test samples when compared to the control. This indicates macrocytic anemia. MCHC measures the average concentration of hemoglobin in each cell. Decreased MCHC as reported in this study suggests iron deficiency anemia (Wanda, 2018). Seasonally, the results of the present study indicate that $\mathrm{Hb}$, $\mathrm{PCV}, \mathrm{RBC}$ and MCHC of the test samples were significantly higher $(\mathrm{p}<0.05)$ in the wet season than in the dry season. Whereas, WBC, MCV and $\mathrm{MCH}$ in the test samples were significantly lower $(\mathrm{p}<0.05)$ in the wet season when compared to dry season. This suggests lower negative impacts of the quarry in the wet season than in the dry season.

\section{CONCLUSION}

There were clear and noticeable adverse effects of the quarry on the liver, kidney and hematological parameters of the albino rats which were higher in the dry season than in the wet season. There was likely, a hepatic damage since liver enzymes and bilirubin were all raised. The kidney function of the rats was also impaired by the effect of the quarry. This is so because all the analyzed kidney function parameters were increased in the albino rats from the quarry. The albino rats also suffered anemia as a result of their exposure to the quarry dust. Therefore, workers in the quarry are at risks of anemia, kidney and liver diseases.

\section{REFERENCES}

1 Aigbokhaode, A.Q., Isah, E.C. and Isara, A.R. (2011) Knowledge and practice of occupational safety practices among quarry workers in a rural community in Edo state, Nigeria. Journal of community Health and Primary Health-care 23 (1\&2): 16-24.

2 Beckman, C. (2007). Synchron clinical system chemistry information manual. Pp 1-14

3 Burtis, C.A., Ashwood, E.R. and Burns, D.E. (2012) Kidney function test-A text book of clinical chemistry and Molecular Diagnostics. Elsevier Health Sciences 25:70-81

4 Chema Diagnostica (2016). Bicarbonate Test Procedure (manual). Chema diagnostic monsano (AN) Italy.

5 Edmund, L. and David, J. (2006). Kidney function tests. In: Carl A. B., Edward, R., David, E. (Editors). Tietz textbook of clinical chemistry and molecular diagnosis $\left(4^{\text {th }}\right.$ ed.). New Delhi: Elsevier Inc; Pp. 797-808

6 Farida,T., Salawu, O.A., Tijani, A.Y. and Ejiofor, J.I. (2012). Pharmacological evaluation of Ipomea asarifolia (Desr.) against carbon tetrachloride-induced hepatotoxicity in rats. Ethnopharmacol. 142: 642-646.

7 Gowda, S., Desai, P., Kulkarni, S.S., Hull, V.V., Math, A.A.K., and Vernekar, S.N. (2010). Markers of renal function test. N. Am. J. med. Sci. 2(4):170-173.

8 Gowda, S., Desai, P.B., Hull, V.V., Math, A.A.K, Vernekar, S.N. and Kulkarni, S.S. (2009). A review on laboratory liver function tests. Pan African medical Journal 11:1-12.

9 Ibrahim, H.M. and Selim, N.M.M. (2018). Soil pollution enhances the accumulation of heavy metals in plants. Asian Journal of Advances in Agricultural research. 6(2): $1-8$.

10 Khan, Z., Nawaz, M., Khan, A. and Bacha, U. (2013). Hemoglobin, red blood cell count, hematocrit and derived parameters for diagnosing anemia in elderly males. Proceedings of the Pakistan Academy of sciences 50(3): 217-226

11 Mohammed, M.I. and Inuwa, Y. (2012). Determination of serum chloride ion concentration in pregnant women from Minjbir local government area, kano State Nigeria. Chemsearch Journal. 3(1): 19-23.

12 Nisha, R., Srinivasa, K.S.R., Thanga, M.K and Jagatha, P. (2017). Biochemical evaluation of creatinine and urea in patients with renal failure undergoing hemodialysis. J. clin path lab. Med. 1(2):1-5

13 Offor, S.J., Mbagwu, H.O.C. and Orisakwe, O.E. (2017) Lead Induced hepato-renal damage in male albino rats and effects of activated charcoal. Front pharmacol. 8(107): 17.

14 Ogugbuaja, V.O., Gwaski, P. and Khan, I.Z. (2004). Environmental toxicology: acute effects of suspended 
particulate matter (dust) on hematological indices of albino rats. Bull. Chen. Soc. Ethiop. 18(2):215-220.

15 Roberto, M., Marcello, C.M. and Letizia, F. (2013). Determination of serum and albumin concentration in Healthy and Diseased Hermann's tortoises (Testudo hermanni): A comparism using electrophoresis and the Bromocresol Green Dye-Binding method. Journal of Herpetological Medicine and surgery 23(1-2): 20-24.

16 Teco Diagnostics (2017). Sodium and Potassium reagent set (manual). Colorimetric method. Teco diagnostics Anaheim, CA 92807 USA.

17 Ugbogu, O.C., Ohakwe, J. and Foltescu, V. (2009). Occurrence of respiratory and skin problems among manual stone quarry workers. African Journal of respiratory medicine 10:23-26.

18 Wanda, L. (2018). The complete blood count and associated tests. RN.Org.SA Pp. 1-30 